\title{
KARAKTERISTIK VEGETASI HABITAT ORANG UTAN (Pongo pygmaeus morio) DI PT. KALTIM PRIMA COAL, KALIMANTAN TIMUR
}

\section{VEGETATION CHARACTERISTICS OF THE ORANG UTAN (Pongo pygmaeus morio) HABITAT AT PT. KALTIM PRIMA COAL, EAST KALIMANTAN}

\author{
Mukhlisi ${ }^{1 *}$, Wawan Gunawan ${ }^{2}$ \\ ${ }^{\text {I} B a l a i}$ Litbang Teknologi Konservasi Sumber Daya Alam (Balitek KSDA), Jl Soekarno Hatta Km 38 Po Box 578 \\ Balikpapan, Kalimantan Timur 76112 \\ ${ }^{2}$ Ditjen Pengendalian Perubahan Iklim (PPI), Kementerian Lingkungan Hidup dan Kehutanan \\ Gedung Manggala Wanabakti Blok 7 Lantai 12 Jl. Jenderal Gatot Subroto, Jakarta \\ *Corresponding author: muci_musci@yahoo.co.id
}

Naskah Diterima: 24 Juli 2018; Direvisi: 3 Oktober 2018; Disetujui: 12 November 2018

\begin{abstract}
Abstrak
Orang utan (Pongo pygmaeus morio) merupakan salah satu primata dilindungi. Sebagian populasinya dapat ditemukan pada Kawasan Reklamasi Pasca Tambang Batubara (KRPT) di PT. Kaltim Prima Coal Sangatta. Penelitian ini bertujuan untuk menganalisis karakteristik vegetasi habitat orang utan di sekitar PT. Kaltim Prima Coal. Metode pengumpulan data vegetasi menggunakan kombinasi jalur berpetak. Hasil penelitian menunjukkan bahwa karakteristik vegetasi habitat orang utan di tiga lokasi KRPT terdiri dari 40 jenis tumbuhan. Sekitar $41-45 \%$ di antaranya merupakan jenis tumbuhan yang dimakan oleh orang utan. Nilai indeks keanekaragaman jenis vegetasi (H') berkisar 1,00-1,09; indeks dominansi (D') berkisar 0,14-0,40; dan indeks keseragaman (E') berkisar 0,91-0,99. Vegetasi pada strata pertumbuhan semai dikuasai oleh paku resam (Dicranopteris linearis) dan ilalang (Imperata cylindrica). Strata pertumbuhan pancang cenderung dikuasai oleh jenis Leea indica dan Flemingia congesta. Sementara itu, vegetasi strata pohon dikuasai oleh jenis tanaman reklamasi yaitu Cassia siamea dan Cassia suratensis. Pola regenerasi vegetasi belum berjalan dengan normal, namun proses suksesi telah berjalan dengan hadirnya jenis-jenis alami. Karakteristik vegetasi tidak ideal bagi habitat orang utan. Peningkatan daya dukung habitat perlu dilakukan melalui pengembangan koridor vegetasi antar fragmen hutan tersisa.
\end{abstract}

Kata kunci: Habitat; Orang utan; PT. Kaltim Prima Coal; Tambang batu bara

\begin{abstract}
Orang utan (Pongo pygmaeus morio) is one of the protected primates. Some of their population might be found in the Mine Closure Area (MCA) at PT. Kaltim Prima Coal Sangatta. The aim of this research was to analyze the characteristics of the vegetation of their habitat at PT. Kaltim Prima Coal. Data was collected by using a combination of line-plot sampling method. The results showed that vegetation characteristic of orang utan habitat in three locations of MCA consisted of 40 plants species, which $41-45 \%$ of the plant species were fed by orang utan. Diversity index $\left(H^{\prime}\right)$, dominance index $\left(D^{\prime}\right)$ and evenness index $\left(E^{\prime}\right)$ were by 1.09-1.00, 0.14-0.40, and 0.91-0.99, respectively. The vegetation on the seedling stage was dominated by Dicranopteris linearis and Imperata cylindrica. The sapling stage was dominated by Leea indica and Flemingia congesta. Meanwhile, the tree stage was dominated by reclamation plants that were Cassia siamea and Cassia suratensis. The regeneration pattern of vegetation has not run normally but the succession process has been starting that indicated by the presence of species naturally. Vegetation characteristics were not ideal for orang utan habitat. Increasing carrying capacity needs to be carried out by developing vegetation corridors among the remaining forest fragments.
\end{abstract}

Keywords: Coal mining; Habitat; Orang utan; PT. Kaltim Prima Coal

Permalink/DOI: http://dx.doi.org/10.15408/kauniyah.v12i1.8629 


\section{PENDAHULUAN}

Pongo pygmaeus morio merupakan satu subspesies orang utan yang memiliki sebaran alami khususnya di sekitar wilayah Kalimantan bagian Timur (Goossens et al., 2009). Berbagai ancaman seperti deforestasi dan degradasi habitat yang berlangsung sejak lama telah menyebabkan penurunan populasi orang utan di Pulau Kalimantan dan Sumatera. Berdasarkan perhitungan Departemen Kehutanan (2007) habitat orang utan Kalimantan telah menyusut sebanyak rata-rata 1,5-2\% per tahun. Fenomena ini menyebabkan status konservasi orang utan berada dalam daftar merah (red list) IUCN (The International Union for Conservation of Nature) pada status endangered (terancam) (Ancrenaz et al., 2008). Secara nasional seluruh subspesies orang utan juga dilindungi melalui Peraturan Menteri Lingkungan Hidup dan Kehutanan No. P.92 Tahun 2018 tentang jenis tumbuhan dan satwa yang dilindungi.

Kawasan konsesi PT. Kaltim Prima Coal (PT. KPC) menjadi salah satu habitat tersisa bagi populasi orang utan di luar kawasan konservasi dengan ciri khas vegetasi hutan sekunder. Secara lanskap kawasan PT. KPC berbatasan langsung dengan Taman Nasional Kutai yang menjadi habitat alami orang utan. Sebagian populasi orang utan di kawasan PT. KPC saat ini menempati kantung-kantung habitat terpisah yang sudah tidak saling terhubung satu sama lain terutama pada bekas kawasan reklamasi pasca tambang (KRPT). Menurut Rayadin et al. (2012) beberapa KRPT di PT. KPC diidentifikasi menjadi habitat bagi sebaran orang utan seperti di KRPT Taman Payau, D2 Surya, Pelikan, dan Mentari dengan populasi diperkirakan pada wilayah tersebut berkisar antara 9,14 sampai 12,01 individu orang utan (dengan rataan 10,48 individu orang utan).

Orang utan menggunakan waktunya dalam sehari untuk aktivitas mencari makan rata-rata 46\% (Krisdijantoro, 2007). Secara alami pada kondisi habitat yang baik sekitar $57 \%$ individu jantan dan $80 \%$ individu betina waktu makannya dihabiskan untuk memakan buah-buahan (Meijaard et al., 2001). Keterbatasan keragaman jenis vegetasi pakan dan ruang pada kondisi hutan sekunder seperti di areal reklamasi PT. KPC saat ini menyebabkan orang utan yang hidup di dalamnya mengembangkan sifat oportunistik. Menurut Meijaard et al. (2001) sifat ini pada dasarnya merupakan perilaku untuk mengkonsumsi apa saja yang dapat diraihnya, karena berada pada kondisi pakan berkurang. Hal tersebut menyebabkan populasi orang utan mampu bertahan meskipun berada di areal hutan sekunder yang terbatas sumber pakannya.

Berkaitan dengan hal tersebut maka dapat dipahami jika karakteristik vegetasi habitat orang utan memberikan pengaruh besar terhadap preferensi kehadiran orang utan dan kualitas daya dukung habitat yang dimiliki. Beberapa penelitian terkait kondisi vegetasi habitat orang utan telah dilakukan, seperti di kawasan hutan Taman Nasional Gunung Palung, Kalimantan Barat (Felton et al., 2003), Batang Toru Sumatera Utara (Simorangkir et al., 2009), dan Taman Nasional Tanjung Putting (Rahman, 2010). Penelitian terkait karakteristik vegetasi habitat orang utan, khususnya pada hutan sekunder KRPT batu bara di PT. KPC masih minim dilakukan. Pengetahuan terkait karakteristik vegetasi habitat orang utan pada areal terfragmentasi seperti di KRPT berperan penting dalam menentukan pemilihan jenis tanaman reklamasi, serta strategi untuk menghindari konflik kepentingan antara orang utan dan manusia.

Berdasarkan uraian di atas, maka penelitian ini perlu dilakukan dengan tujuan untuk menganalisis karakteristik vegetasi habitat orang utan pada KRPT PT. Kaltim Prima Coal area Sangata di Kalimantan Timur. Hasil penelitian ini diharapkan dapat menjadi salah satu landasan kebijakan yang dapat dimanfaatkan untuk manajemen habitat satwa liar, khususnya orang utan pada areal terfragmentasi. Hal ini dimaksudkan agar kegiatan penambangan batu bara dan upaya konservasinya dapat dilakukan secara beriringan.

\section{MATERIAL DAN METODE}

Penelitian ini dilakukan di Kawasan Reklamasi Pasca Tambang Batu bara (KRPT) PT. Kaltim Prima Coal (PT. KPC), khususnya pada site Sangata, meliputi KRPT Taman Payau, AB East, dan Telaga Batu Arang. 
Pengumpulan data penelitian dilakukan pada Bulan Agustus dan September 2014. Metode pengumpulan data dalam penelitian ini dilakukan dengan inventarisasi vegetasi menggunakan pendekatan metode jalur berpetak sepanjang $100 \mathrm{~m}$ (0,2 ha). Dalam metode ini setiap jalur transek terdapat petak ukuran 20x20 m untuk pengamatan strata pertumbuhan pohon (setiap tumbuhan dengan diameter $\geq 10 \mathrm{~cm}$ ), petak ukuran $5 \times 5 \mathrm{~m}$ untuk pengamatan strata pertumbuhan pancang

Kerapatan (Ki)

Kerapatan relatif (KRi)

Frekuensi (Fi)

Frekuensi relatif (FRi)

Dominansi (Di)

Dominansi relatif (DRi)

Luas bidang dasar (LBDS)

$$
\begin{aligned}
& =\frac{\text { Jumlah individu jenis } \mathrm{i}}{\text { Total luas petak yang dibuat }} \\
& =\frac{\mathrm{Ki}}{\text { Jumlah Ki seluruh jenis }} \times 100 \%
\end{aligned}
$$$$
=\frac{\text { Jumlah petak ditemukan jenis i }}{\text { Jumlah petak yang dibuat }}
$$$$
=\frac{\mathrm{Fi}}{\text { Jumlah Fi seluruh jenis }} \times 100 \%
$$$$
=\frac{\text { Jumlah LBDS jenis } \mathrm{i}}{\text { Total luas petak yang dibuat }}
$$

$$
\begin{aligned}
& =\frac{\text { Di }}{\text { Jumlah Di seluruh jenis }} \times 100 \% \\
& =1 / 4 \cdot \pi \cdot \mathrm{d}^{2}
\end{aligned}
$$

Seluruh data yang diperoleh ditabulasikan untuk mengetahui indeks nilai penting (INP) untuk setiap jenis tumbuhan pada setiap strata dengan rumus:
INP semai
$: \mathrm{KR}+\mathrm{FR}$
INP pancang dan pohon $\quad:$ KR + FR + DR

Nilai indeks keanekaragaman jenis dihitung menggunakan indeks keanekaragaman jenis Shannon-Wienner (H') pada setiap strata pertumbuhan. Selain itu juga dilakukan analisis data terhadap nilai indeks keseragaman (E') dan indeks dominansi (D').

\section{HASIL}

\section{Komposisi Jenis}

Komposisi jenis tumbuhan penyusun habitat orang utan di tiga lokasi KRPT PT. KPC mencirikan sebagai vegetasi hutan sekunder dengan dominasi jenis pionir dan keragaman yang rendah. KRPT Telaga Batu Arang dan Taman Payau adalah kawasan reklamasi tertua dibandingkan KRPT AB East karena telah direklamasi sejak tahun 19961998, sedangkan KRPT AB East baru direklamasi sejak tahun 2003.
Komposisi jenis pohon penyusun vegetasi di sekitar areal KRPT PT. KPC terutama berasal dari jenis tanaman reklamasi yang bersifat cepat tumbuh (fast growing) seperti Cassia siamea dan Paraserianthes falcataria yang ditemukan tersebar merata dengan diameter 20-30 cm. Strata pertumbuhan semai atau anakan dari kedua jenis tersebut justru tidak ditemukan. Beberapa jenis tumbuhan pionir yang ditemukan di antaranya adalah Dicranopteris linearis, Ficus sp., Macaranga gigantea, Neonauclea gigantea, serta Vitex pinnata. Berikut ini adalah hasil identifikasi komposisi jenis dan analisis beberapa parameter indeks vegetasi di tiga lokasi KRPT PT. KPC yang menjadi kantung habitat penting bagi orang utan (Tabel 1).

\section{Struktur Vegetasi}

Hasil analisis vegetasi pada strata semai di tiga lokasi KRPT PT. KPC berhasil teridentifikasi 29 jenis tumbuhan. KRPT Telaga Batu Arang mempunyai komposisi jenis paling tinggi mencapai 12 jenis. KRPT Taman Payau dan AB East relatif memiliki 
jumlah jenis yang lebih sedikit masing-masing 8 jenis dan 9 jenis. Hasil perhitungan lima jenis tumbuhan dengan Indeks Nilai Penting (INP) tertinggi pada strata semai ditampilkan secara lengkap pada Tabel 2.

Struktur vegetasi pada strata pancang dicirikan dengan penguasaan jenis tumbuhan pionir, terutama jenis Leea indica. Jenis tumbuhan ini memiliki dominansi paling tinggi di KRPT Taman Payau (INP 75,57\%) dan AB East (INP 103,16\%), sedangkan jenis tumbuhan Flemingia congesta menjadi jenis tumbuhan paling dominan untuk KRPT Telaga Batu Arang dengan INP 74,49\%. Secara keseluruhan hasil identifikasi jenis tumbuhan strata pancang pada KRPT Taman Payau ditemukan 12 jenis, $\mathrm{AB}$ East 5 jenis, dan Telaga Batu Arang 17 jenis. Hasil lengkap hasil perhitungan INP pada strata pancang ditampilkan pada Tabel 3 .

Vegetasi strata pohon memiliki peran penting bagi keberadaan orang utan, karena selain berperan sebagai pohon pakan juga sebagai sebagai pohon sarang. Orang utan memilih pohon yang yang cukup besar sebagai sarang. Berdasarkan hasil analisis vegetasi pada tiga lokasi berhasil teridentifikasi 6 jenis pohon pada KRPT Taman Payau, 4 jenis pohon di KRPT AB East, dan 15 jenis pohon di KRPT Telaga Batu Arang. Hasil lengkap perhitungan INP 5 jenis pohon dominan ditampilkan pada Tabel 4.

Tabel 1. Komposisi jenis tumbuhan di areal KRPT PT. KPC

\begin{tabular}{|c|c|c|c|c|c|c|c|c|c|}
\hline \multirow{3}{*}{ Jenis } & \multicolumn{9}{|c|}{ Kawasan Reklamasi Pasca Tambang } \\
\hline & \multicolumn{3}{|c|}{ Taman Payau } & \multicolumn{3}{|c|}{$\mathrm{AB}$ East } & \multicolumn{3}{|c|}{ Telaga Batu Arang } \\
\hline & $\mathrm{Se}$ & $\mathrm{Pc}$ & $\mathrm{Ph}$ & $\mathrm{Se}$ & $\mathrm{Pc}$ & $\mathrm{Ph}$ & $\mathrm{Se}$ & $\mathrm{Pc}$ & $\mathrm{Ph}$ \\
\hline Bridelia glauca* & & & & & & & + & + & \\
\hline Cassia siamea* & & + & + & & & + & & + & + \\
\hline Cassia suratensis* & & & & & & & & + & + \\
\hline Clidemia hirta* & & & & & & & + & & \\
\hline Cratoxylum sumatrana & & & & & & & & + & + \\
\hline Croton argyratus* & & + & & & & & & & \\
\hline Dicranopteris linearis & & & & + & & & + & & \\
\hline Dillenia excelsa* & & & & & & & & + & + \\
\hline Dioscorea sp. & + & & & & & & & & \\
\hline Ficus sp.* & & & & & + & & & + & + \\
\hline Flemingia congesta & & & & & & & & + & \\
\hline Fordia splendidissima* & & & & & & & + & + & + \\
\hline Glochidion sp.* & & & & + & & & & & \\
\hline Guioa sp. & & & & & & & + & & \\
\hline Hibiscus tiliaceus* & & & + & & & & & & \\
\hline Imperata cylindrica & & & & + & & & & & \\
\hline Leea indica & + & + & & + & + & & & + & \\
\hline Litsea sp.* & & + & & & & & & & \\
\hline Lygodium sp.* & & & & & & & + & & \\
\hline Macaranga gigantea* & & & & + & & & + & & + \\
\hline Mallotus paniculatus & & + & & + & + & & & + & + \\
\hline Melastoma malabathricum* & & + & & + & + & & & + & \\
\hline Merremia peltata* & + & & & & & & & & \\
\hline Mikania micrantha & + & & & & & & & & \\
\hline Mimosa pudica & + & & & & & & & & \\
\hline Neonauclea gigantea* & & + & & & & & & & + \\
\hline Nephrolepsis bisserata & + & & & & & & + & & \\
\hline Paraserianthes falcataria* & & & + & & & + & & & + \\
\hline Piper aduncum* & & & & & + & + & + & + & + \\
\hline Pternandra rostrata & & & & & & & & & + \\
\hline Pterospermum javanicum* & & & & & & & & & + \\
\hline Pueraria javanica* & & & & + & & & + & & \\
\hline
\end{tabular}




\begin{tabular}{|c|c|c|c|c|c|c|c|c|c|}
\hline \multirow{3}{*}{ Jenis } & \multicolumn{9}{|c|}{ Kawasan Reklamasi Pasca Tambang } \\
\hline & \multicolumn{3}{|c|}{ Taman Payau } & \multicolumn{3}{|c|}{$\mathrm{AB}$ East } & \multicolumn{3}{|c|}{ Telaga Batu Arang } \\
\hline & $\mathrm{Se}$ & $\mathrm{Pc}$ & $\mathrm{Ph}$ & $\mathrm{Se}$ & $\mathrm{Pc}$ & $\mathrm{Ph}$ & $\mathrm{Se}$ & $\mathrm{Pc}$ & $\mathrm{Ph}$ \\
\hline Saccharum sp. * & + & & & & & & & & \\
\hline Samanea saman $*$ & & & + & & & & & & \\
\hline Scaphium macropodum* & & & & & & & & + & \\
\hline Scleria sumatrana & + & & & + & & & + & & \\
\hline Shorea seminis* & & + & & & & & & & \\
\hline Tristaniopsis whiteana & & & & & & & & & + \\
\hline Vernornia arborea* & & & & & & & + & + & + \\
\hline Vitex pinnata* & & + & + & & & & & + & + \\
\hline Komposisi Jenis & 8 & 9 & 5 & 9 & 5 & 3 & 12 & 15 & 16 \\
\hline Indeks $H^{\prime}$ & & 1,07 & & & 1,00 & & & 1,09 & \\
\hline Indeks D’ & & 0,14 & & & 0,40 & & & 0,34 & \\
\hline Indeks E' & & 0,97 & & & 0,91 & & & 0,99 & \\
\hline
\end{tabular}

Keterangan: $(*)$ : Tumbuhan sumber pakan orang utan; (+): Jenis yang hadir/teridentifikasi Se: strata semai; Pc: strata pancang; Ph : strata pohon

Tabel 2. Indeks Nilai Penting (INP) 5 jenis tumbuhan strata semai dominan di areal KRPT PT. KPC

\begin{tabular}{|c|c|c|c|c|}
\hline $\begin{array}{c}\text { KRPT Taman Payau } \\
\text { Jenis }\end{array}$ & Suku & KR & FR & $\operatorname{INP}(\%)$ \\
\hline Nephrolepsis bisserata & Dryopteridaceae & 35,90 & 9,09 & 44,99 \\
\hline Scleria sumatrana & Cyperaceae & 24,79 & 18,18 & 42,97 \\
\hline Clidemia hirta & Melastomataceae & 9,40 & 18,18 & 27,58 \\
\hline Acrostichum aureum & Pteridaceae & 13,68 & 9,09 & 22,77 \\
\hline Mimosa pudica & Leguminosae & 5,13 & 13,64 & 18,76 \\
\hline \multicolumn{5}{|l|}{ KRPT AB East } \\
\hline Jenis & Suku & $\mathrm{KR}$ & FR & $\operatorname{INP}(\%)$ \\
\hline Imperata cylindrica & Poaceae & 31,89 & 10,34 & 42,23 \\
\hline Dicranopteris linearis & Gleicheniaceae & 27,17 & 6,90 & 34,06 \\
\hline Mallotus paniculatus & Euphorbiaceae & 3,15 & 13,79 & 16,94 \\
\hline Pueraria javanica & Leguminosae & 5,91 & 6,90 & 12,80 \\
\hline Scleria sumatrana & Cyperaceae & 2,36 & 10,34 & 12,70 \\
\hline $\begin{array}{c}\text { KRPT Telaga Batu Arang } \\
\text { Jenis }\end{array}$ & Suku & $\mathrm{KR}$ & FR & INP $(\%)$ \\
\hline Dicranopteris linearis & Gleicheniaceae & 24,85 & 11,90 & 36,75 \\
\hline Scleria sumatrana & Cyperaceae & 13,33 & 9,52 & 22,86 \\
\hline Piper aduncum & Piperaceae & 14,55 & 7,14 & 21,69 \\
\hline Parasarianthes falcataria & Fabaceae & 18,18 & 2,38 & 20,56 \\
\hline Fordia splendidissima & Leguminosae & 6,67 & 7,14 & 13,81 \\
\hline
\end{tabular}

Tabel 3. Indeks Nilai Penting (INP) 5 jenis tumbuhan strata pancang dominan di areal KRPT PT. KPC

\begin{tabular}{llcccc}
\hline $\begin{array}{l}\text { KRPT Taman Payau } \\
\text { Jenis }\end{array}$ & \multicolumn{1}{c}{ Suku } & KR & FR & DR & INP (\%) \\
\hline Leea indica & Leeaceae & 43,24 & 14,29 & 15,04 & 72,57 \\
Cassia siamea & Fabaceae & 13,51 & 14,29 & 17,15 & 44,95 \\
Vitex pinnata & Verbenaceae & 2,70 & 7,14 & 33,40 & 43,25 \\
Croton argiratus & Euphorbiaceae & 2,70 & 7,14 & 14,77 & 24,61 \\
Mallotus paniculatus & Euphorbiaceae & 13,51 & 7,14 & 3,75 & 24,41 \\
\hline
\end{tabular}




\begin{tabular}{llcccc}
\hline \begin{tabular}{l} 
KRPT AB East \\
\multicolumn{1}{c}{ Jenis }
\end{tabular} & \multicolumn{1}{c}{ Suku } & KR & FR & DR & INP $(\%)$ \\
\hline Leea indica & Leeaceae & 11,11 & 16,67 & 75,38 & 103,16 \\
Mallotus paniculatus & Euphorbiaceae & 38,89 & 33,33 & 5,29 & 77,52 \\
Melastoma malabathricum & Melastomataceae & 27,78 & 16,67 & 10,44 & 54,89 \\
Piper aduncum & Piperaceae & 16,67 & 16,67 & 2,49 & 35,83 \\
Ficus sp. & Moraceae & 5,56 & 16,67 & 6,38 & 28,61 \\
\hline KRPT Telaga Batu Arang & & & & \\
\multicolumn{1}{c}{ Jenis } & Suku & KR & FR & DR & INP $(\%)$ \\
\hline Flemengia congesta & Fabaceae & 41,18 & 19,27 & 14,04 & 74,49 \\
Piper aduncum & Piperaceae & 10,59 & 15,41 & 10,72 & 36,73 \\
Cassia suratensis & Fabaceae & 5,88 & 3,85 & 19,65 & 29,38 \\
Leea indica & Vitaceae & 10,59 & 3,85 & 5,42 & 19,86 \\
Ficus sp. & Moraceae & 3,53 & 3,85 & 11,46 & 18,85 \\
\hline
\end{tabular}

Tabel 4. Indeks Nilai Penting (INP) 5 jenis tumbuhan strata pohon dominan di areal KRPT PT. KPC

\begin{tabular}{llcccc}
\hline $\begin{array}{l}\text { KRPT Taman Payau } \\
\text { Jenis }\end{array}$ & \multicolumn{1}{c}{ Suku } & KR & FR & DR & INP $(\%)$ \\
\hline Cassia siamea & Fabaceae & 65,22 & 36,36 & 35,35 & 136,93 \\
Paraserianthes falcataria & Fabaceae & 15,22 & 27,27 & 49,63 & 92,12 \\
Hibiscus tiliaceus & Malvaceae & 10,87 & 9,09 & 7,39 & 27,36 \\
Gmelina arborea & Malvaceae & 4,35 & 18,18 & 4,75 & 27,28 \\
Vitex pinnata & Verbenaceae & 2,17 & 9,09 & 1,88 & 13,14 \\
\hline KRPT AB East & & & & & \\
$\quad$ Jenis & Suku & KR & FR & DR & INP $(\%)$ \\
\hline Cassia siamea & Fabaceae & 54,84 & 12,77 & 35,97 & 103,58 \\
Paraserianthes falcataria & Fabaceae & 22,58 & 29,79 & 44,62 & 96,99 \\
Gmelina arborea & Verbenaceae & 16,13 & 44,68 & 18,46 & 79,27 \\
Macaranga gigantea & Euphorbiaceae & 6,45 & 12,77 & 0,94 & 20,16 \\
\hline KRPT Telaga Batu Arang & & & & & \\
$\quad$ Jenis & $\quad$ Suku & KR & FR & DR & INP $(\%)$ \\
\hline Cassia suratensis & Fabaceae & 32,89 & 17,95 & 23,68 & 74,52 \\
Cassia siamea & Fabaceae & 32,89 & 17,95 & 21,34 & 72,19 \\
Ficus sp. & Moraceae & 1,32 & 2,56 & 29,00 & 32,88 \\
Cratoxylum sumatarana & Hypericaceae & 7,89 & 12,82 & 6,72 & 27,44 \\
Macaranga gigantea & Euphorbiaceae & 7,89 & 7,69 & 9,20 & 24,79 \\
\hline
\end{tabular}

\section{PEMBAHASAN}

Variasi komposisi jenis penyusun vegetasi pada habitat orang utan di masingmasing KRPT PT. KPC sangat dipengaruhi oleh umur tanaman areal reklamasi, tingkat gangguan manusia, proses suksesi yang terjadi, serta jarak dari hutan utuh sebagai sumber benih alami (Rayadin et al., 2012; Mukhtar \& Heriyanto, 2012; Komara et al., 2018). Sebagai contoh, letak KRPT Telaga Batu Arang yang bersebelahan dengan kawasan konservasi Taman Nasional Kutai memiliki komposisi jenis vegetasi lebih tinggi dibandingkan dengan KRPT Taman Payau yang jauh dari petak hutan utuh, meskipun keduanya samasama telah direklamasi sejak tahun 1996-1998. Pola regenerasi yang belum berjalan normal mengindikasikan jika proses suksesi vegetasi baru menginjak fase hutan sekunder muda. Hal ini selaras dengan pernyataan Kennard (2002) serta Saharjo dan Gago (2011) bahwa jika suatu kawasan hutan tropis mengalami gangguan maka dibutuhkan setidaknya 15-20 tahun untuk membentuk kembali hutan sekunder muda. Selanjutnya, 50 tahun 
kemudian berangsur-angsur akan terbentuk hutan sekunder tua dengan vegetasi klimaks.

KRPT Taman Payau memiliki persentase komposisi tumbuhan pakan yang tertinggi dibandingkan dua lokasi studi lainnya, sehingga menjadi pilihan untuk feeding ground bagi orang utan di PT. KPC. Hasil ini sesuai dengan hasil studi Rayadin et al. (2012) yang menyebutkan jika lokasi ini pilihan habitat bagi orang utan dengan ditandai banyaknya sarang orang utan. Meskipun demikian, sebetulnya KRPT Taman Payau belum dapat dikatakan memiliki daya dukung habitat ideal bagi orang utan, sebab persentase jenis tumbuhan pakannya masih di bawah $60 \%$. Bismark et al. (2009) menyebutkan bahwa dalam kondisi ideal habitat orang utan seharusnya dapat ditemukan $60 \%$ jenis tumbuhan pakan dimana dari jumlah tersebut setidaknya $80-90 \%$ merupakan pohon penghasil buah. Orang utan dapat beradaptasi pada kondisi hutan yang miskin jenis tumbuhan pakannya karena bersifat oportunis, memakan apa saja yang dapat diraihnya (Meijaard et al., 2001). Fenomena ini terlihat jelas di sebagian besar lokasi studi dimana jenis pohon Cassia siamea, Cassia suratensis dan Paraserianthes falcataria menjadi jenis yang juga dimakan, padahal ketiga jenis tersebut merupakan tanaman reklamasi dari kelompok eksotis yang tidak ditemukan di habitat alaminya. Studi lain yang dilakukan oleh Mukhlisi et al. (2017) orang utan di fragmen hutan perkebunan kelapa sawit juga memakan kambium dari kulit tumbuhan dari jenis-jenis Macaranga spp dan tunas muda sawit untuk beradaptasi pada kondisi habitat yang miskin tumbuhan pakan utamanya.

Hasil perhitungan nilai indeks keanekaragaman jenis $(\mathrm{H})$ di ketiga lokasi KRPT berkisar antara 1,00-1,09. Bila dikaitkan dengan parameter indeks keanekaragaman jenis Shannon Winner maka nilai ini termasuk kategori sedang (1-2), namun mendekati rendah. Keanekaragaman jenis tumbuhan yang tinggi sangat diperlukan bagi orang utan untuk meningkatkan adaptasi terhadap kondisi lingkungan sekitar. Meijaard et al. (2001) menyatakan bahwa pada kondisi ideal orang utan cenderung menyukai habitat yang memiliki variasi jenis dan komposisi tumbuhan yang beragam, karena membutuhkan variasi dan jenis makanan yang sangat tinggi. Kuswanda (2013) melaporkan bahwa variasi komposisi jenis tumbuhan pakan terutama pada strata tiang dan pohon akan mempengaruhi peluang kehadiran orang utan pada sebuah habitat.

Ditinjau dari nilai indeks keseragaman (E) tampak jika nilai yang hampir sama pada setiap lokasi kantung habitat orang utan dengan kisaran 0,91-0,99 sedangkan nilai indeks Dominansi (D) berkisar 0,14-0,49. Menurut Odum (1998) nilai indeks keseragaman yang tinggi akan diikuti nilai indeks dominansi yang rendah, kondisi ini memiliki arti jika komunitas tumbuhan berada pada kondisi relatif stabil. Nilai indeks keseragaman yang mendekati angka 1 ini menunjukkan bahwa setiap jenis tumbuhan tersebar secara merata dan hampir tidak ada jenis tumbuhan yang mendominasi dalam satu komunitas vegetasi. Kondisi ini diikuti oleh nilai indeks dominansi jenis yang rendah bahkan cenderung mendekati nilai 0 (nol), sehingga dapat diartikan bahwa tidak ada jenis yang paling dominan di lokasi penelitian. Kawasan AB East terlihat memiliki indeks dominansi paling tinggi bila dibandingkan dengan kawasan lainnya dengan nilai indeks dominansi 0,40. Hal ini diduga berkaitan erat dengan umur tanaman reklamasi yang lebih rendah bila dibandingkan dengan dua KRPT lainnya sehingga proses pertumbuhan alami jenis-jenis lain belum berjalan secara merata.

Struktur vegetasi strata semai berperan penting untuk menyamarkan keberadaan orang utan dari predator atau bentuk ancaman lain yang berpotensi untuk mengganggunya (Loken et al., 2015; Ancrenaz et al., 2014). Orang utan sebagai satwa primata pada dasarnya bersifat arboreal, namun individu orang utan di Kalimantan terkadang memiliki kebiasaan turun ke permukaan tanah untuk mencari makan atau berjalan terutama pada kondisi habitat yang terganggu/terbuka dan terfragmentasi (Ancrenaz et al., 2014). Penyamaran ini didukung oleh kondisi lantai hutan yang banyak ditutupi oleh jenis-jenis tumbuhan paku (Nephrolepsis bisserata dan Dicranopteris inearis), serta ilalang (Imperata cylindrica). Tingginya tingkat penguasaan tumbuhan paku dan ilalang pada strata semai adalah bagian alami dari proses suksesi. 
Kelompok tumbuhan tingkat rendah memang kerap hadir lebih awal untuk mengkolonisasi, sebab mampu beradaptasi pada kondisi lahan terbuka dan miskin hara. Yassir et al. (2010) melaporkan bahwa dalam proses suksesi, kelompok tumbuhan bawah tersebut tersebut secara berangsur-angsur akan menghilang dan digantikan jenis tumbuhan semai berhabitus kayu. Proses ini pun telah terjadi pada lokasi studi dengan ditandai hadirnya jenis tumbuhan alami strata semai berhabitus kayu, seperti Mallotus paniculatus dan Fordia splendidissima.

Kehadiran tumbuhan strata pancang penting dalam proses regenerasi sebuah komunitas vegetasi. Jenis Leea indica merupakan salah satu jenis tumbuhan yang mampu hadir secara alami, bukan dari proses penanaman kegiatan reklamasi, dan bahkan memiliki INP tertinggi di KRPT Taman Payau dan AB East. Jenis ini termasuk jenis tumbuhan pionir dan memiliki peran vital sebagai sumber pakan satwa liar yang hidup disekitarnya. Leea indica diketahui menjadi salah satu pakan alami orang utan di Danum Valley, Sabah (Kanamori et al., 2010) pada saat penelitian ini dilakukan rusa sambar (Rusa unicolor) teramati memakan tunas dan bagian daun yang masih muda. Bagi orang utan tumbuhan strata pancang mempunyai peran sebagai salah satu variabel penting dalam menentukan preferensi habitatnya. Lebih lanjut Kuswanda (2013) menjelaskan kehadiran variasi jenis tumbuhan pada strata pancang telah meningkatkan peluang kehadiran orang utan di hutan Batang Toru, sebab dapat akan memudahkan orang utan dalam bergerak dan mencari makan.

Struktur vegetasi pada strata pohon dikuasai oleh jenis-jenis eksotis yang digunakan untuk reklamasi, terutama Cassia siamea dan Cassia suratensis. Hasil penelitian Mukhtar dan Heriyanto (2012) juga menunjukkan jika pada beberapa areal reklamasi lain di PT. KPC, seperti KRPT H East Dump I, Cassia siamea dan Cassia suratensis sangat mendominasi dengan kerapatan pohon berturut-turut adalah 124 individu/ha dan 128 individu/ha. Hasil observasi di lapangan memperlihatkan jenisjenis pohon tersebut selain dimakan juga kerap digunakan sebagai pohon sarang. Orang utan sering terlihat mengkonsumsi terutama bagian bunga dan daun muda Cassia siamea maupun Cassia suratensis.

Dalam studi ini juga berhasil diidentifikasi beberapa jenis tumbuhan non tanaman reklamasi yang berhasil tumbuh hingga strata pohon, seperti Vitex pinnata, Ficus sp., dan juga Macaranga gigantea. Dalam konteks reklamasi, Adman (2013) menyebutkan jika jenis Vitex pinnata dapat digunakan sebagai jenis tanaman lokal untuk reklamasi pasca tambang batu bara berdasar hasil uji coba penanaman di areal reklamasi tambang batu bara PT. Singlurus Pratama dengan persentase tumbuh di atas $90 \%$. Kehadiran pohon-pohon tersebut mengindikasikan proses suksesi yang berlangsung dengan baik. Ficus sp. diketahui selain sebagai jenis tanaman pakan bagi orang utan juga memiliki fungsi sebagai tanaman bagi satwa liar lainnya terutama burung karena mampu menghasilkan buah dalam jumlah melimpah sepanjang tahun.

\section{SIMPULAN}

Karakteristik vegetasi habitat orang utan di Kawasan Reklamasi Pasca Tambang (KRPT) di PT. KPC dicirikan sebagai hutan sekunder muda yang tersusun atas 40 jenis tumbuhan. Setiap lokasi KRPT pada strata pohon masih didominasi oleh tumbuhan eksotis hasil tanaman reklamasi. Sementara itu, pada strata pancang dan semai mulai didominasi oleh tumbuhan pionir khas hutan sekunder dan semak belukar. Dalam penelitian ini hanya ditemukan $41-45 \%$ dari total jenis pohon yang teridentifikasi dikonsumsi oleh orang utan. Dengan demikian, dapat dinyatakan bahwa persentase jumlah tumbuhan pakan tersebut belum mencukupi kondisi ideal daya dukung habitat bagi orang utan.

\section{UCAPAN TERIMA KASIH}

Penulis mengucapkan terimakasih dan penghargaan kepada pimpinan dan staf PT. Kaltim Prima Coal (PT. KPC), khususnya bagian Health, Safety, and Environment (HSE) yang telah memberikan izin dan memfasilitasi kegiatan selama studi dilakukan. Penulis juga mengucapkan terimakasih kepada Amir Ma'ruf dan Warsidi yang telah membantu proses pengumpulan data di lapangan. 


\section{REFERENSI}

Adman, B. (2013). Uji coba penanaman sepuluh jenis pohon lokal pada lahan pasca tambang batubara di PT. Singlurus Pratama Kalimantan Timur. In I. Yassir, \& A. Puspanti (Eds.), . Prosiding Seminar Reklamasi Lahan Pasca Tambang: Aspek Kebijakan, Konservasi, dan Teknologi. Balai Penelitian Teknologi Konservasi Sumber Daya Alam, Samboja, Indonesia.

Ancrenaz, M., Marshall, A., Goossens, B., van Schaik, C., Sugardjito, J., Gumal, M., \& Wich, S. (2008). Pongo pygmaeus. The IUCN Red List of Threatened Species. (2008, July 1). Retrieved from http://www.iucnredlist.org.

Ancrenaz, M., Sollmann, R., Meijaard, E., Hearn, A. J., Ross, J., Samejima, H., Loken, B., Cheyne, S. M., Stark, D. J., Gardner, P. C., Goossens, B., Mohamed, A., Bohm, T., Matsuda, I., Nakabayasi, M., Lee, S. K., Bernard, H., Brodie, J., Wich, S., Fredriksson, G., Hanya, G., Harrison, M. E., Kanamori, T., Kretzschmar, P., Macdonald, D. W., Riger, P., Spehar, S., Ambu, L., \& Wilting, A. (2014). Coming down from the trees: is terrestrial activity in Bornean orangutans natural or disturbance driven?. Scientific Report, 4(4024), 1-5.

Bismark, M. (2009). Tata ruang reklamasi tambang batubara di PT. Kaltim Prima Coal. In H. Priyono, D. Purwito, T. S. Hadi, \& N. Juliaty (Eds.), Prosiding Workshop IPTEK Penyelamatan Hutan Melalui Rehabilitasi Lahan Bekas Tambang Batubara. Balai Besar Penelitian Dipterokarpa, Samarinda, Indonesia.

Departemen Kehutanan. (2007). Strategi dan rencana aksi konservasi orang utan Indonesia 2007-2017. Jakarta: Departemen Kehutanan.

Felton, A. M., Engstrom, L. M., Felton, A., \& Knott, C. D. (2003). Orangutan population density, forest structure and fruit availability in hand-logged and unlogged peat swamp forest in West Kalimantan, Indonesia. Biological Conservation, 114(1), 91-101.
Goossens, B., Chikhi, L., Jalil, M. F., James, S., Ancrenaz, M., Lackman-Ancrenaz, I., \& Bruford, M. W. (2009). Taxonomy, geographic variation and population genetics of Bornean and Sumatran orangutans. In S. Wich, S. S. U. Atmoko, T. M Setia, \& C. P. van Schaik (Eds.), Orangutans geographic variation in behavioral ecology and conservation (pp.77-96). New York, USA: Oxford University Press.

Loken, B., Spehar, S., \& Rayadin, R. (2015). Terrestriality in the Bornean orangutan (Pongo pygmaeus morio) and implications for their ecology and conservation. American Journal of Primatology, 75(11), 1129-38.

Peraturan Menteri Lingkungan Hidup dan Kehutanan Nomor.

P92.MenLHK/Setjen/Kum.1/8/2018

tentang perubahan atas Peraturan Menteri Lingkungan Hidup dan Kehutanan Nomor P.20/MenLHK/Setjen/Kum.1/6/2018 tentang jenis tumbuhan dan satwa yang dilindungi. (2018, September 5). Retrieved from http://ksdae.menlhk.go. id/assets/news/peraturan/P.20_Jenis_TSL .pdf.

Kennard, D. K. (2002). Secondary forest succession in a tropicaldry forest: patterns of development across a 50-year chronosequence in lowland Bolivia. Journal of Tropical Ecology, 18(1), 5366.

Kanamori, T., Kuze, N., Bernard, H., Malim, T. P., \& Kohshima, S. (2010). Feeding ecology of Bornean orangutans (Pongo pygmaeus morio) in Danum Valley, Sabah, Malaysia: a 3-year record including two mast fruitings. American Journal of Primatology, 72(9), 1-21.

Kartawinata, K., Soenarko, S., Tantra, I. G. M., \& Samingan, T. (1976). Pedoman inventarisasi flora dan ekosistem. Bogor: Direktorat Perlindungan dan Pengawetan Alam.

Komara, L. L., Choesin, D. N., \& Syamsuddin, T. S. (2018). Plant diversity after sixty years post coal mining in East Kalimantan, Indonesia. Biodiversitas, 17(2), 531-538. 
Krisdijantoro, A. (2007). Analisis pola penggunaan ruang dan waktu orangutan (Pongo pygmaeus pygmaeus Linneaus, 1760) di Hutan Mentoko Taman Nasional Kutai Kalimantan Timur (Pascasarjana Tesis). Institut Pertanian Bogor, Bogor.

Kuswanda, W. (2013). Seleksi sumberdaya habitat orangutan (Pongo abelii Lesson 1827) di Cagar Alam Sipirok, Sumatera Utara. Jurnal Penelitian Hutan dan Konservasi Alam, 10(3), 255-277.

Mukhtar, A. S., \& Heriyanto, N. M. (2012). Keadaan suksesi tumbuhan pada kawasan bekas tambang batubara di Kalimantan Timur. Jurnal Penelitian Hutan dan Konservasi Alam, 9(4), 341350.

Mukhlisi., Ma'ruf, A., \& Putro, J. A. (2017). Komposisi dan kelimpahan pakan orang utan (Pongo pygmaeus morio) di sekitar perkebunan kelapa sawit PT. Anugerah Energitama Kalimantan Timur, Fakultas Pertanian Universitas Mulawarman, Samarinda.

Meijaard, E., Rijksen, H. D., \& Kartikasari. (2001). Di ambang kepunahan kondisi orangutan liar di awal abad ke-21. Jakarta: The Gibbon Foundation Indonesia.

Odum, E. P. (1998). Dasar-dasar ekologi edisi ketiga. Yogyakarta: Gajah Mada University Press.
Rahman, D. A. (2010). Karakteristik habitat dan preferensi pohon sarang orangutan (Pongo pygmaeus Wurmbii) di Taman Nasional Tanjung Puting (Studi kasus camp lekay). Jurnal Primatologi Indonesia, 7(2), 37-50.

Rayadin, Y., Boer, R. C., Masrun, H., Rochmadi, S., Sutrisman, A., Hanggito, M. S., \& Syamsudin, J. (2012). Analisis distribusi populasi dan perilaku ekologi orangutan pada kawasan reklamasi pasca tambang PT. Kaltim Prima Coal. Samarinda: PT. KPC-Ecositrop-Unmul.

Saharjo, B. H., \& Gago, C. (2011). Suksesi alami paska kebakaran pada hutan sekunder di Desa Fatuquero, Kecamatan Railaco, Kabupaten Ermera-Timor Leste. Jurnal Silvikultur Tropika, 2(1), 40-45.

Simorangkir, R. H., Mansjoer, S. P., \& Bismark, M. (2009). Struktur dan komposisi pohon di habitat orangutan liar (Pongo abelii), kawasan Hutan Batang Toru, Sumatera Utara. Jurnal Primatologi Indonesia, 6(2), 10-20.

Soerianegara, I., \& Indrawan, A. (1982). Ekologi hutan Indonesia. Bogor: Laboratorium Ekologi Hutan Fakultas Kehutanan IPB.

Yassir, I., van der Kamp, J., \& Buurman, P. (2010). Secondary succession after fire in imperata grasslands of East Kalimantan, Indonesia. Agriculture, Ecosystems and Environment, 137(1), 172-182. 